\title{
Five New Records for Turkish Robber Flies (Diptera: Asilidae) Fauna
}

\author{
Hakan ÇALIŞKAN ${ }^{1, *} \quad$ Davut Ümit ŞiRIN² $\quad$ Adem ASLAN $^{3}$ \\ Ebru Ceren FIDAN ${ }^{4} \quad$ Yalçın ŞAHIN ${ }^{5}$ \\ 1, 2, 4Eskisehir Osmangazi University, Faculty of Science and Letters, Biology Department, \\ Eskisehir, TURKEY \\ ${ }^{3}$ Eskisehir Osmangazi University, Mahmudiye ,Horse Breeding Vocational School, Eskisehir, \\ TURKEY \\ ${ }^{5}$ Ogretmenler Street, 69 /3 Visnelik, Eskisehir, TURKEY \\ E-mails: 1,*hakan@ogu.edu.tr, ${ }^{2}$ usirin@ogu.edu.tr, ${ }^{3}$ aaslan@ogu.edu.tr, \\ ${ }^{4}$ cerenkkayki@gmail.com, ${ }^{5}$ yalcinsahin.biology@gmail.com \\ ORCID IDs: ${ }^{1, *} 0000-0001-7879-6449,{ }^{2} 0000-0001-7327-4043,{ }^{3} 0000-0003-2269-9417$, \\ ${ }^{4} 0000-0002-6121-4585,{ }^{5} 0000-0002-3681-8600$
}

\section{ABSTRACT}

We here record five robber fly (Asilidae) species [Lasiopogon cinctus (Fabricius, 1781), Stenopogon mediterraneus Lehr, 1963, Saropogon longicornis (Macquart, 1838), Machimus arthriticus (Zeller, 1840), Machimus gonatistes (Zeller, 1840)] belonging to three subfamilies and four genera for the first time in Turkey. While all species are reported from Turkish Thrace, one of is also from Anatolia. Distributional data and taxonomical remarks with photographs of male genitalia and habitus for each species are given.

Key words: Asilidae, robber flies, new records, Turkish Thrace,Turkey.

Çalışkan, H., Şirin, D.Ü., Aslan, A., Fidan, E.C, \& Şahin, Y. (2020). Five new records for Turkish robber flies (Diptera: Asilidae) fauna. Journal of the Entomological Research Society, 22(3), 239-254. 
ÇALIŞKAN, H., ŞIRIN, D.Ü., ASLAN, A., FIDAN, E.C, \& ŞAHIN, Y.

\section{INTRODUCTION}

Asilidae is one of the largest families of Diptera with 7104 species and 89 subspecies (Geller-Grimm, 2015). The members of this family are commonly named as robber flies. The adult and larvae of robber flies are predacious in nature. They feed on various arthropods, mainly insects, and so play an important role in keeping the balance of insect populations (Lehr, 1988). Adult robber flies attack wasps, bees, dragonflies, grasshoppers, other flies, and some spiders (Shurovnekov, 1962). These flies are known to have a large variety of species in mostly dry and sunny habitats (Theodor, 1980).

Considering the species diversity of family, as well as the biodiversity potential of Turkey, our knowledge about Turkish robber fly fauna is still insufficient. Until 1981, there was limited information about the species living in Anatolia, obtained especially from studies conducted by foreign researchers such as Séguy (1927), Engel (1930), Jansens (1968a, 1968b) and Tsacas (1968). The first checklist of the family in Anatolia was published by Giray in 1981. In his work, he summarized all data published in the past as well as his own unpublished findings and reported 131 species in Turkey. After 13 years, the robber fly fauna of Erzurum and adjacent provinces were evaluated by Hayat and Alaoglu in their three articles (Hayat \& Alaoglu, 1994, 1996a, 1996b). Also, three new records for Turkey were reported by Hayat \& Özbek (1994). Weinberg \& Hayat (1997) published a checklist of Turkish robber flies including 180 species. Then, two new species were described by Hasbenli \& Geller-Grimm (1999). Hayat \& Özbek (1999) reported two new records of genus Dasypogon. Also another six species were recorded by Durmuş (1999) for the first time from Turkey at his MSc thesis. In the same year, Tomasovic (1999a, 1999b) reported three species from Turkey for the first time. Bosak \& Hradsky (2001) published a comprehensive study on Asilidae fauna in Turkey. They recorded 24 species of totally 102 records as new species from the country and stated 210 species living in Turkey. Six species were recorded for the first time from Turkey by Çalışkan (2003). Hasbenli, Candan, \& Alpay (2006a) described a new species from the genus Leptogaster. Additionally, three new records, one of them from the genus Erax and the others from Neoitamus, were published by Hasbenli, Bayrakdar, \& Alpay (2006b) and Hasbenli \& Bayrakdar (2006). In the following year, 3 species belonging to the Leptaogastrinae subfamily were recorded by Aral-Alpay, Aktaş, \& Hasbenli (2007) for the first time. Two years later, two Dioctria species were reported for the first time by Bayrakdar \& Hasbenli (2009) and a new species belonging to Mesoleptogaster was described by Hasbenli \& Çağlar (2009). Çalışkan (2010) reported Pamponerus germanicus as a new record for the country. Aral-Alpay (2011) stated that one species of Machimus, four species of Tolmerus and one of Eutolmus were reported for the first time from Turkey in her $\mathrm{PhD}$ thesis. The last faunistic data on Turkish robber flies fauna was published by Hasbenli, Çiftçi, \& Çağlar (2020). In this study, they described the new genus Tanap and the new species Tanap cinar Hasbenli \& D. Çiftçi, 2020 belonging to the Dioctriinae subfamily from Turkey.

The latest version of the "Catalogue of World Robber flies" lists 60 genus, 228 species and 9 subspecies for Turkey (Geller-Grim, 2015). However, the following seven species reported in different studies from Turkey; Leptogaster fumipennis Loew, 1871, 
Five New Records for Turkish Robber Flies (Diptera: Asilidae) Fauna

Leptogaster truncata Theodor, 1980, Leptogaster montana Theodor, 1980 (Aral-Alpay et al, 2007), Mesoleptogaster cappadocia Hasbenli \& Çağlar, 2009 (Hasbenli \& Çağlar, 2009), Pamponerus germanicus (Linnaeus, 1758) (Çalışkan, 2010) and Machimus aberrans (Schiner, 1868), Tolmerus lesinensis Palm, 1876 Loew (Aral-Alpay, 2011) are not in this catalog.

In this study, we report five species for the first time in Turkey. Thus, Turkish robber flies are represented by 63 genera, 241 species and 9 subspecies, together with the seven species that were not included in the list before, a new genus and a new species reported by Hasbenli et al (2020) and our new records.

\section{MATERIAL AND METHODS}

The specimens were collected with entomological net from meadows, fields, rivers edges, bridges, forests and residential areas in Turkish Thrace in 2002, 2003, 2005, 2018 and 2019.

A total of 342 specimens, 174 males and 168 females, were examined. All specimens are preserved in the Entomology Collection of Eskişehir Osmangazi University, Arts and Science Faculty, Eskişehir, Turkey. Material was studied according to methods described by Theodor (1976), with the aid of a stereomicroscope (Leica MZ 16) and photographed by Leica DFC 490 imaging system. Identifications were made using the keys and descriptions by Weinberg \& Bachli (1995), Lehr (1963, 1984, 1986,1992), Theodor (1976, 1980), Cannigs (2002) and Astakhov (2015). The nomenclature follows that of Geller-Grimm, Dikow, \& Lavinge (2020).

\section{RESULTS AND DISCUSSION}

Lasiopogon cinctus (Fabricius, 1781), Stenopogon mediterraneus Lehr, 1963, Saropogon longicornis (Macquart, 1838), Machimus arthriticus (Zeller, 1840), and Machimus gonatistes (Zeller, 1840) are reported for the first time from Turkey. For all species, details of examined material, distribution data and brief descriptions of them are given. In addition, our observations and taxonomic evaluations of the specimens are presented under the title of "Remarks".

\section{STENOPOGONINAE}

\section{Lasiopogon Loew,1847}

\section{Lasiopogon cinctus (Fabricius, 1781) (Fig. 1A-E; Fig. 2)}

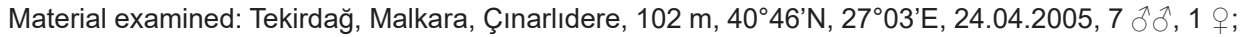

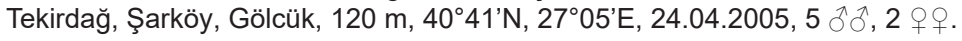

Distribution: Austria, Belgium, Belarus, Bulgaria, Czech Republic, Denmark, Finland, France, Greece, Germany, Hungary, Italy, Norway, Poland, Romania, Soviet Union (North European territory, Central European territory, South European territory), Spain, Sweden, Switzerland, Netherlands, United Kingdom, former Yugoslavia (Geller-Grimm, 2015; Sakhvon \& Caxboh, 2015). 
ÇALIŞKAN, H., ŞIRIN, D.Ü., ASLAN, A., FIDAN, E.C, \& ŞAHIN, Y.

\section{Description}

Body: 8-10 mm, Wings: 6-8 mm

Head: Vertex has a wide opening that is half the width of the head. The facial gibbosity is large, the face and frons are brownish, the facial beard black, spread to leave small gaps in the upper and lateral parts of the face. The lower half of the head and especially the posterior part of the eyes are grayish white and long thin white pubescent. The upper half behind the head is brownish, the hairs behind the eyes at the top of the head are long and curved forward. In the vertex, the hairs are long and extend into 2 segments of the antenna. Proboscis is shiny black, the palls are short, thin and black. The antenna is grayish brown and black. Segment 1 is longer than segment 2 and segments $1+2$ is longer than half of the 3rd segment. Segments 1 and 2 carry black hairs. Stylus thick.

Thorax: Mesonotum is brownish yellow, humeral callus, button-shaped prominent, thin, small, black-haired. The brown band extending from the humeral calluses towards the posterior reaches the scutellum by bending. The brown band in the middle extends to the tranverse suture. Setae: 2 Presutural, 3 supraalar, 1 strong long, 2 weak short postalar, dorsocentral 5 pairs strong, long, black, 2 pairs of these setae before the suture, (Additionally there are also 2 smaller setae in front of these). Pleura grayish brown, 6-7 weak setae on the upper part of the rear edge of the Mesopleura. Metapleura 7-9 setae in a row. Scutellum is grayish brown, bare and flat, half disc shaped. There are 10-12 setae in different thickness and length.

Legs: are black. Coxae gray hairs anteriorly, bare posteriorly, whitish yellow hairs at the bottom of fore and middle femur, black hairs at fore and middle tibia, and all the setae are black. White hairs in the ventral of hind femur. The hind tibia has short white hairs and with some black setae. In hind legs, coxal peg present.

Wings: with light brown veins.

Abdomen: is brown or black. Tergites are grayish at the posterior and lateral edges. The anterior is black, dark brown, near the middle area rectangle. Bristle are gray-white. It becomes sparse on the sides from $1^{\text {st }}$ to $4^{\text {th }}$ tergite. In the first three segments, hairs are longer than others. Hypopygium of male and ovipositor of female in bright black. Male hypopygium has dense black hairs on it, female ovipositor carries short acanthoforites with 13 spines (on the left side 6 spines and right side 6 spines separate and a weak sipine in the middle).

Genitalia: Male genitalia is wide and rotated $180^{\circ}$. The two halves of epandrium are completely separate. Apex of the aedeagus is a trifid shaped. Apodeme of hypandrium and gonocoxite complex is very long and strong, spatula shaped. Apical lobes of gonocoxite are broadly rounded. Form of dististylus apex is like a finger with processes and longer than its width.

\section{Remarks}

Lasiopogon cinctus are known to be widespread especially in Balkan countries and the European continent. The presence of the species in Turkish Thrace is an expected result. We examined totally 15 specimens (12 male and 3 female) of this 
Five New Records for Turkish Robber Flies (Diptera: Asilidae) Fauna

species collected two different sites in Tekirdağ provinces. Morphological features of our specimens mostly confirm to description of this species in Lehr (1984) and Cannings (2002). So far it is known that there are two species of the genus Lasiopogon living in Turkey (Geller-Grimm, 2015). L. cinctus is the third species of Lasiopogon recorded from Turkey.
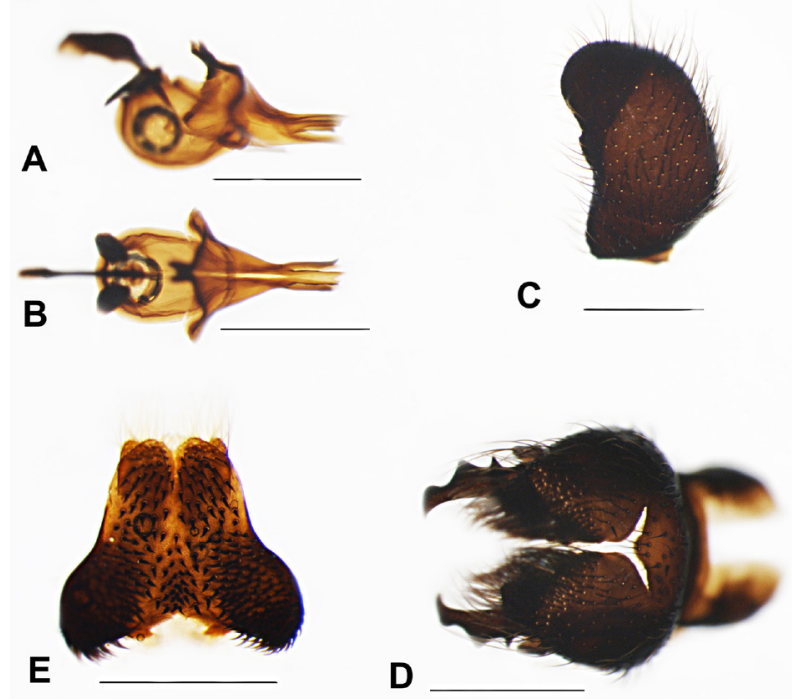

Fig. 1. Male genitalia of Lasiopogon cinctus (Fabricius, 1781). a. aedeagus (lateral), b. aedeagus (dorsal), c. epandrium, d. gonocoxite and dististylus, e. subepandrial sclerite (Scale 0,5 mm).

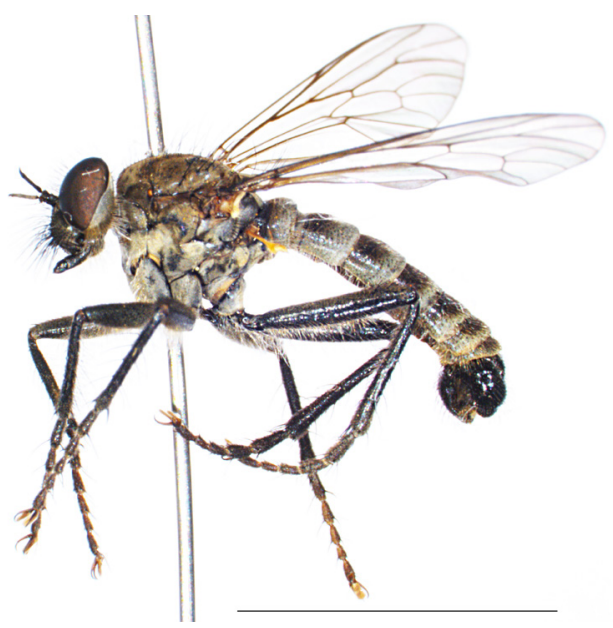

Fig. 2. Lasiopogon cinctus (Fabricius, 1781). Male (Scale $5 \mathrm{~mm}$ ). 
ÇALIŞKAN, H., ŞIRIN, D.Ü., ASLAN, A., FIDAN, E.C, \& ŞAHIN, Y.

\section{Stenopogon Loew, 1847}

\section{Stenopogon mediterraneus Lehr, 1963 (Fig. 3A-E; Fig. 4)}

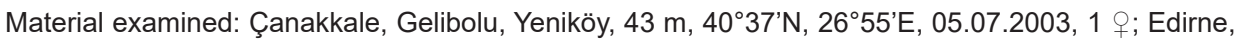
Uzunköprü, Karapınar, $56 \mathrm{~m}, 41^{\circ} 6^{\prime} \mathrm{N}, 26^{\circ} 38^{\prime} \mathrm{E}, 06.07 .2003,80^{\lambda}{ }^{\lambda}, 8$ 우; Edirne, Değirmenyeni, $58 \mathrm{~m}$, $41^{\circ} 43^{\prime} \mathrm{N}, 26^{\circ} 33^{\prime} \mathrm{E}, 07.07 .2003,4$ ổ $^{\prime}, 4$ 우우; Edirne, Keşan, Çobançeşmre, $93 \mathrm{~m}, 40^{\circ} 56^{\prime} \mathrm{N}, 2^{\circ} 39^{\prime} \mathrm{E}$,

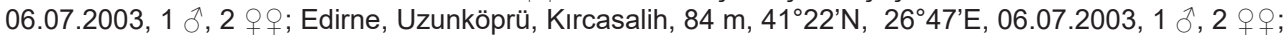

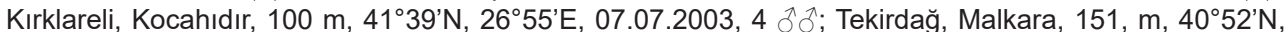

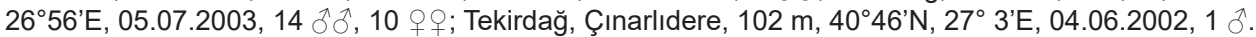

Distribution: Albania and Greece (Geller-Grimm, 2015).

Description

Body: 21-26 mm, Wings: 12,5-15 mm

Head: Head is circular, all setae and hairs are yellow. Antennae; segment 1 and segment 2 are red, segment 3 is dark red or dark red in all segments in some specimens. Segment 1 is longer than 2 , segment 3 is slightly longer than $1+2$.

Thorax: is yellowish. the humeral callus is reddish, brown; and some specimens is slightly dark, median stripe brown. Setae: 8-10 humeral, 6-9 posthumeral, 4-5 notopleural, 10-14 supraalar, 6-8 postalar, 14-16 dorsocentral, 6-9 sucutellar (The setae are aligned to the right and left sides of the back edge of the sucutellum).

Legs: The anterior femora is with a half black band along the femur on both sides, from the femoral base to the apical. The inner band is smaller. The middle leg femur carries a black band tapering from the base to $3 / 2$ apical. Hind femora with a black band along the femora on the outer lateral surface of the femora in male. The black band of the femora sometimes may be shorter, and not extend to the apical in female.

Abdomen: is yellowish brown, some of the specimens' tergites are red anteriorly, dark brown posteriorly in male. Hypopygium red or dark reddish. The last 2-3 segments and ovipositor are dark reddish brown in female.

Genitalia: Male genitalia is yellow and reddish, bristle color is yellow. Hypandrium has got two lobes that are separated on both sides of the apical part. These parts are yellow hairy.

\section{Remarks}

The most important taxonomic character used to distinguish between the species of Stenopogon is the structure of the hypandrium. According to Lehr (1963), the apex of the hypandrium of Stenopogon mediterraneus have two lobes as in S. callosus (Pallas, 1818), but the lobes in the hypandrium of $S$. mediterraneus are slightly curved on both sides. In present study, we examined 33 males and also 27 females from eight different localities. The hypandirum structures of our male specimens are similar to original description (Fig. 3E). Furthermore, we observed light yellow and slightly dark specimens in color and also have color differences between female and male individuals.

The species was described by Lehr (1963) in Albania and it is known to exist only in Macedonia outside of the type locality (Adamovic, 1966). So, our record is the eastern 
Five New Records for Turkish Robber Flies (Diptera: Asilidae) Fauna

boundary of the distribution area of the species. However, 18 species of this genus are known to exist in Turkey and this number has increased to nineteen with our record.

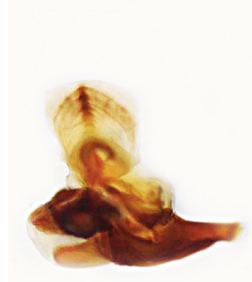

A

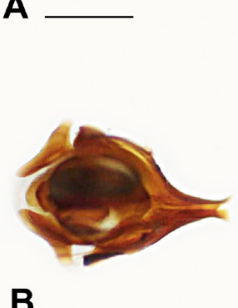

B
E
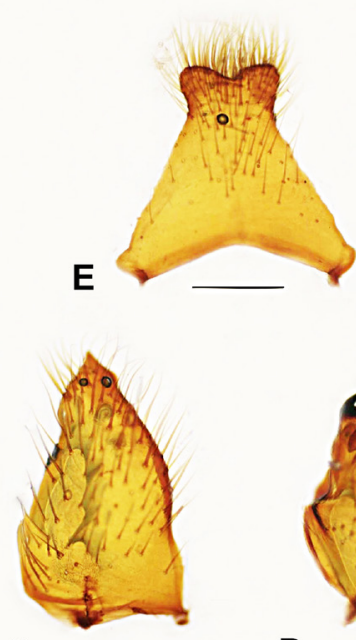

C

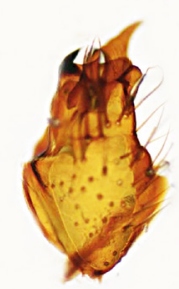

D

Fig. 3. Male genitalia of Stenopogon mediterraneus Lehr, 1963. a. aedeagus (lateral), b. aedeagus (dorsal), c. epandrium, d. gonocoxite and dististylus e. hypandrium (Scale 0,5 mm).

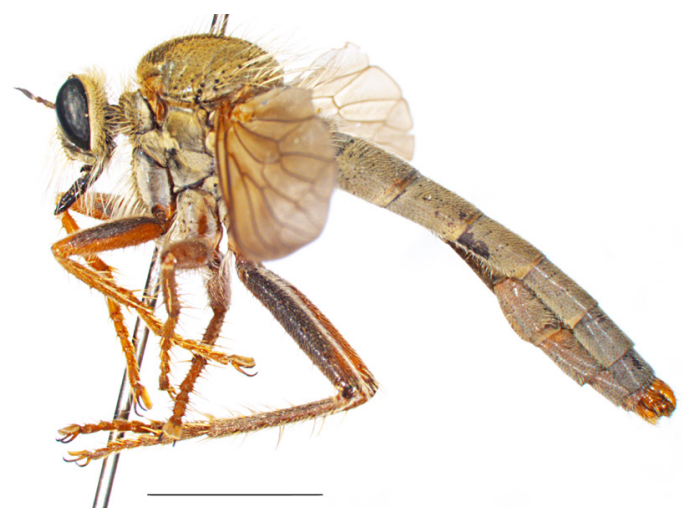

Fig. 4. Stenopogon mediterraneus Lehr, 1963. Male (Scale 5 mm).

\section{DASYPOGONINAE}

\section{Saropogon Loew, 1847}

\section{Saropogon longicornis (Macquart, 1838) (Fig. 5A-E; Fig. 6)}

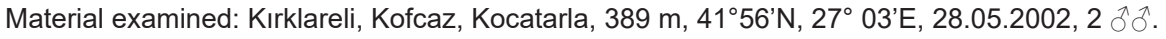

Distribution: Egypt, Iran, Israel (Ghahari, Hayat, Lavigne, \& Ostovana, 2014; Geller-Grimm, 2015) 
ÇALIŞKAN, H., ŞIRIN, D.Ü., ASLAN, A., FIDAN, E.C, \& ŞAHIN, Y.

\section{Description}

Body:11-12 mm, Wings: $9 \mathrm{~mm}$

Head: facial tomentum yellow, facial beard yellow, frons with gray tomentum, black in the middle, in the form of a strip. Ocellar tubercule is black, with two reddish spot behind the ocellar tubercule. Occipital setae are black on the sides, yellowish in the middle. The antennae are cylindrical, thin and significantly longer over the head. Segment 1 is longer than 2, and the segment 3 is 1.5 times longer than $1+2$. Style fused with segment 3 , a sensillium is situated in the dorsal cavity. Segment 1, 2 and base of segment 3 is reddish, apical part is more or less black. Palps are black.

Thorax: pronotum is black in color with black and black - yellow setae. Mesonotum is black. It carries a gray band from the humeral callus to the scutellum on both sides. This band reaches the back of the suture. Very small black hairs cover mesonotum. The posterior area is bare. Pleura is black, mesopleura dorsally has gray striped-shaped tomentum. Postnotal fan has a row of reddish black setae. Setae: 1-2 (short, reddish black) humeral, 3 notopleural, 2 supraalar (reddish black), 2 postalar, 2-3 dorsocentral (very short), 4 scutellar (black). The wings are brownish yellow, anteriorly dark. M3 cell open, anal cell closed.

Legs: Coxa and trohanter are black, femur base and half is colored black. The fore and middle femora and tibia are light red or orange, base of the fore and middle basitarsus is yellow, dark anteriorly. Hind femora red apically, dark posteriorly. The base of the hind tibia is red, black apically, tarsals are black.

Abdomen: all tergits are black and covered with small black hairs. Posterior of the sternite 2-3 is sligihtly reddish in the form of a thin band.

Genitalia: Aedegus is conical, curved on both sides at the tip. Epandrium, imcompletely divided. Apical processes of the proctiger are not curved. The apical processes from the gonocoxide is long and pointed, the ventral process are triangular. Hypandrium at the base is wide, triangular and with setae.

\section{Remarks}

Saropogon longicornis (Macquart, 1838) is known to date only in Iran, Israel and Egypt. In this study, it is reported for the first time from the European continent. Individuals of the species were caught in a single locality in Kırklareli province.

According to Engel (1930) and Theodor (1980), S. Iongicornis mesonotum: medially black, humeral calli, lateral stripe and posterior part reddish, with greyish tomentum in the anterior part to the suture or slightly beyond. Legs: coxae black, fore and mid trochanters yellowish-red, hind trochanters black or also partly yellowish. Abdomen: tergites 1-7 reddish-yellow in male, with lateral black spots of varying size on tergites or spots absent. Some sternites reddish - yellow. Hypopygium black laterally, reddishyellow dorsally in the middle. Male genitalia: Dististylus slender, tapering, strongly curved, with pointed apex. Proctiger with broad, rounded, inward-curved lateral posterior processes with setae before the apex and with two rounded processes. 
Five New Records for Turkish Robber Flies (Diptera: Asilidae) Fauna

In this study, some differences in body structure and male genitalia were observed in the two S. longicornis specimens examined by us, as follows: mesonotum: there is a gray band from the humeral callus to the scutellum on both sides. This band reaches the back of the suture. Very small black hairs cover mesonotum. The posterior area is bare. Legs: coxa and trochanter are black, femur base and half is colored black. The fore and middle femora and tibia are light red or orange, base of the fore and middle basitarsus is yellow, anteriorly dark. Hind femora red apically, dark posteriorly. The base of the hind tibia is red, black apically, tarsals are black. Abdomen: all tergites black. Male genitalia: Apical processes of the proctiger are not curved. Dististylus slender, tapering, uncurved, with pointed apex. Coloration of the legs is similar to Sarapogan eucerus. The typical structure of the aedeagus, the shape of the epandrium and hypandrium are consistent with the Sarapogon longicornis stated by Theodor (1980). Theodor (1980) states that variations can be seen in body color and male sexual organs of Sarapogon species living in different habitats. Likewise, we think that the observed differences in body coloring of our samples can be considered as variation.

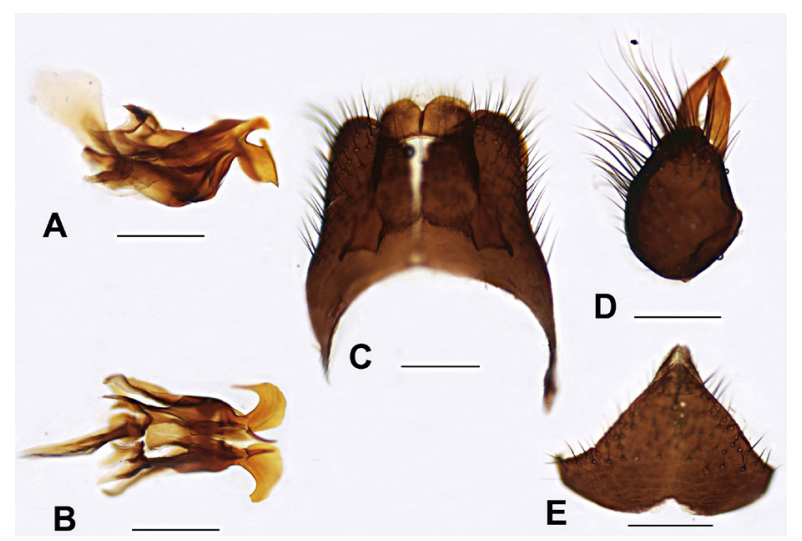

Fig. 5. Male genitalia of Saropogon longicornis (Macquart, 1838). a. aedeagus (lateral), b. aedeagus (dorsal), c. epandrium, d. gonocoxite and dististylus, e. hypandrium (Scale 0,5 mm).

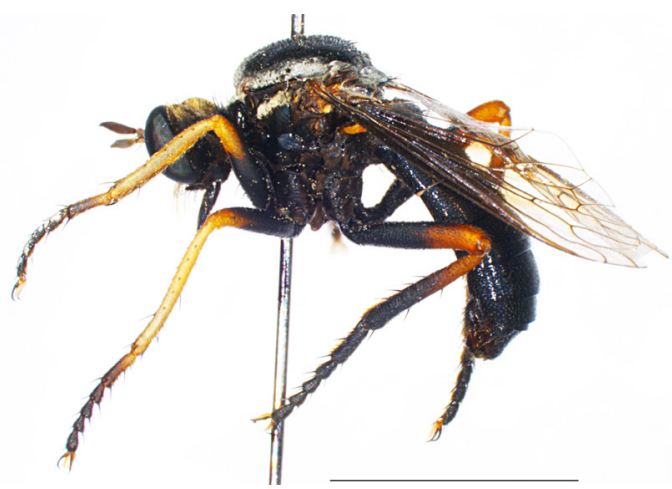

Fig. 6. Saropogon longicornis (Macquart, 1838). Male (Scale $5 \mathrm{~mm}$ ). 
ÇALIŞKAN, H., ŞIRIN, D.Ü., ASLAN, A., FIDAN, E.C, \& ŞAHIN, Y.

\section{ASILINAE}

Machimus Loew, 1849

Machimus arthriticus (Zeller, 1840) (Fig. 7A-E; Fig. 8)

Material examined: Kırklareli, Vize, Pazarlı, $241 \mathrm{~m}, 41^{\circ} 36^{\prime} \mathrm{N}, 27^{\circ} 43^{\prime} \mathrm{E}, 09.07 .2003,1$ đ̊; Tekirdağ,

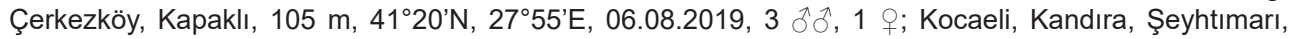

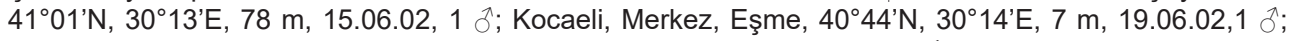

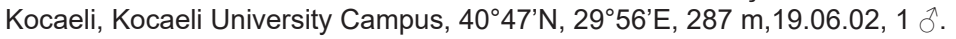

Distribution: Austria, Belarus, Bulgaria, Denmark, Finland, France, Germany, Italy, The Netherlands, Norway, Poland, Romania, Russia, Spain, Sweden, Switzerland, United Kingdom (Geller-Grimm, 2015; Sakhvon \& Caxboh, 2015).

\section{Description}

Body: 14-15 mm, Wings: 8-9 mm

Head: Face has gray-white tomentum. Behind the head, some specimens have white setaes, some have a strong number of black setae among white setaes, or very few (one or few more) among the white setae. Genae and postgenae beard is completely white, facial gibbosity is more or less rusty yellow in color, black hairs are seen towards the upper edge. Palps are black. Antennae: segment 1 is longer than segment 2 , segment 3 is approximately $1+2$ tall.

Thorax: Mesonotum yellowish-brown. Median stripe is brown, wide anteriorly and reached to the scutellum. Setae: 1-2 posthumeral, 2 notopleural, 2 supralar, 3 postalar ( 1 setae is white), 6 pairs dorsocentral setae, the last two pairs, pass the transversal suture, scutellar 2. Hairs color is white.

Legs: The dorsal of the femur and tibia are black and the ventral is brownish. Fore coxae covered with thick and long whitish hairs. Fore femora, carries a row of spine ventrally.

Abdomen: There are white setae on the posterior edges of the tergites. All short hairs are white. The male hypopygium is smaller than the second abdominal segment. It is colored with dark red - brown. It's covered with white hair.

Genitalia: Aedeagus curved at the base. Dististliyus shape is characteristic. It is curved at the base, very short, with wide and angular at the apex. Gonocoxite broadly rounded, with a small, pointed process in the middle of the apical margin.

\section{Remarks}

Machimus arthriticus is widespread in Europe and also spread Bulgaria and Romania in the Balkan Peninsula. In this study, we found the species in two localities from Kırklareli and Tekirdağ provinces in the Thrace region, and also in three localities in Kocaeli province, east of the Bosphorus. So, its record in the east of the Bosphorus indicates that it can be spread to the western parts of Anatolia. Zeller (1840) compared $M$. arthriticus with Asilus genualis, the synonym of $M$. rusticus (Meigen, 1820). The same researcher stated that although this species is significantly smaller than $M$. 
Five New Records for Turkish Robber Flies (Diptera: Asilidae) Fauna

rusticus as body, its body form, color and feathering are similar to it. Schiner (1862) described this species as Epitriptus arthriticus. Zeller (1840) and Schiner (1862) stated that the male genitalia of this species is smaller than the second abdominal segment in the length and the legs are black generally but its basal part is red brown. Similarly, the length of the genitalia of our male specimens is observed to be smaller than the second abdominal segment. However, the femurs of the legs are black in the dorsal and brown in the ventral. Additionally, in our collection it was observed that the setae behind the head were white in some individuals, or some of with strong black setae among the white setae, and others with black setae between the white seta and feathers. It is thought that the difference in leg colors should be compared with other populations in Palearctic and that the difference in seta colors could be the variation of the species. On the other hand, male genitalia structures of the specimens are compatible with the descriptions of Theodor (1976) and Lehr (1992).

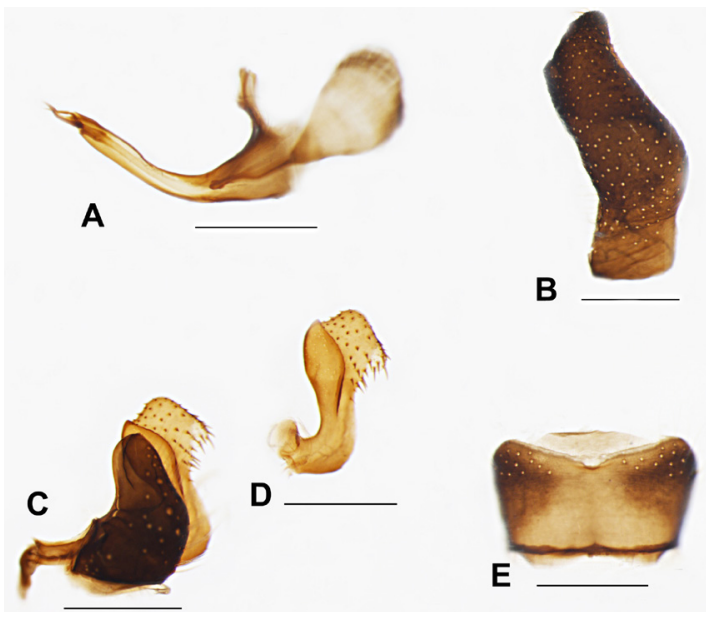

Fig. 7. Male genitalia of Machimus arthriticus (Zeller, 1840). a. aedeagus (lateral), b. epandrium, c. gonocoxite and dististylus, d. dististylus, e. hypandrium (Scale 0,5 mm).

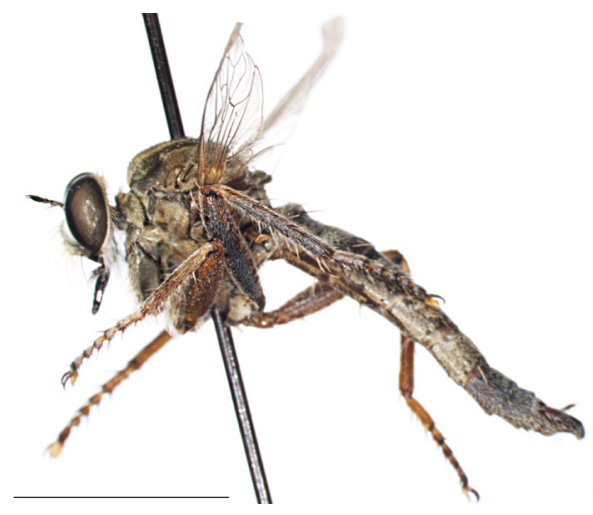

Fig. 8. Machimus arthriticus (Zeller, 1840). Male (Scale $5 \mathrm{~mm}$ ). 
ÇALIŞKAN, H., ŞIRIN, D.Ü., ASLAN, A., FIDAN, E.C, \& ŞAHIN, Y.

Machimus gonatistes (Zeller, 1840) (Fig. 9A-F; Fig. 10)

Material examined: Edirne, Karaağaç, $58 \mathrm{~m}, 41^{\circ} 40^{\prime} \mathrm{N}, 26^{\circ} 31^{\prime} \mathrm{E}, 31.05 .2002,4$ o $\delta^{\prime} ; 07.07 .2003,1$

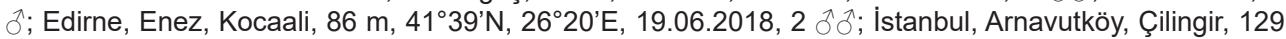

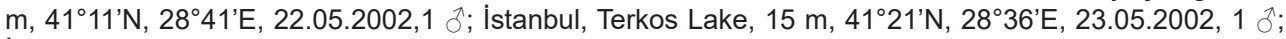

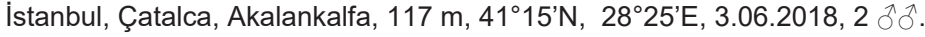

Distribution: Austria, Belarus, Bulgaria, Denmark, Finland, Greece, Germany, Hungary, Italy, Kazakhstan, Morocco, North Africa, Poland, Romania, Russia, Switzerland, Tunisia, former Yugoslavia (Geller-Grimm, 2015; Sakhvon \& Caxboh, 2015).

\section{Description}

Body: 18-23 mm, Wings: $12-14 \mathrm{~mm}$

Head: Face has gray tomentum, face beard has white setae on bottom, and black on top. Facial gibbosty is large, the genea towards the palpels are black with 2-3 black hairs, palp is black and hairs are black. The antennae are black, with gray tomentum and lateral surface of the 1st and 2 nd segment of antennae are gray tomentum. Segment 1 has strong black and weak white hairy. Segment 1 is also longer than segment 2 . Segment 3 is around $1+2$ long. Style is long. Vertex is with long, black strong hairy. A row of black hairs up to the antennae on both sides. Behind the vertex and posterior lateral of the eyes have white hairs, strong black hairs on both sides.

Thorax: Acrostichal hairs short, extend to the front of mesonotum. Humeral callus has white and black hairs. 1-2 posthumeral, 2 notopleural, 2-3 supraalar (1 white), 2 postalar (1 black, 1 white), 8-9 pairs dorsocentral (5 pairs after transversal suture), 5-6 scutellar, the scutellum has long, black and white hairs. Thorax and pleura has gray tomentum, post notal fan with one row, long white hair, in mesopleuron with 1 strong black seta in ventrally.

Wings and veins are brown. In legs, coxa has white hairs, hairs on all legs are white, setae are black. Reddish brown in a small area at basal part of tibia.

Abdomen: in the posterior of tergites, setae are yellowish white, hairs are white, posteriorly and laterally with gray tomentum.

Genitalia: Hairs color are yellowish-white. Lateral progs of the aedeagus are curved. The apical of the epandrium is straight and wide. The dististylus is curved, its base is narrow, it extends towards the apical and the apex is round and has a small protrusion.

\section{Remarks}

Machimus gonatistes is known as a steppe species. It has a wide distribution area in the Palearctic Region and its presence in the Balkan Peninsula is also known (Richter, 1964; Geller-Grimm, 2015). Therefore, it is not surprising that the species is determined in Thrace. The species was only in five localities in the broad study area. This situation is thought to be due to the habitat preference of the species. The morphological characteristics of the 11 males examined in the study generally confirm to its descriptions in Theodor (1976) and Lehr (1992). However, we observed remarkable differences that there was no posterior branch of both wing M3 cells of a sample captured in Istanbul 
Five New Records for Turkish Robber Flies (Diptera: Asilidae) Fauna

Gaziosmanpaşa. Similarly, supraalar and postalar setae are black in the specimens collected from Istanbul Gaziosmanpaşa, whereas these setae are yellow in individuals collected from Edirne. We think that the difference in the vein can be an anomaly and there is a variation in the differences in the setae coloration.

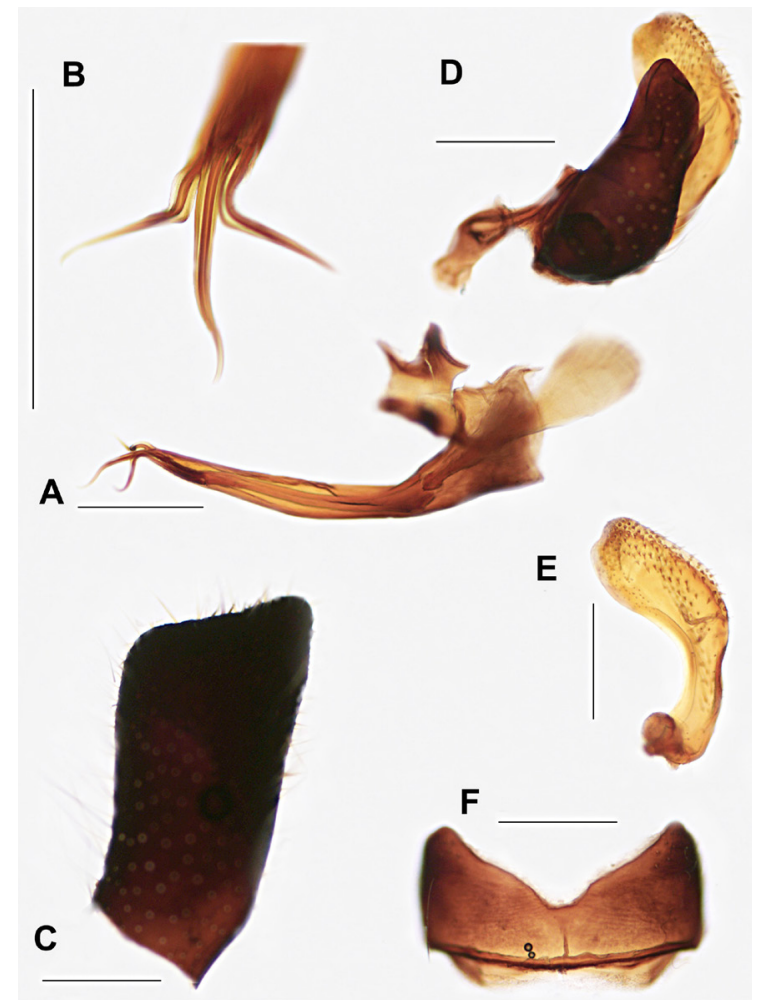

Fig. 9. Male genitalia of Machimus gonatistes (Zeller, 1840). a. aedeagus (lateral), b. end of the aedeagus (dorsal), c. epandrium, d. gonocoxite and dististylus, e. dististylus, f. hypandrium (Scale 0, $5 \mathrm{~mm}$ ).

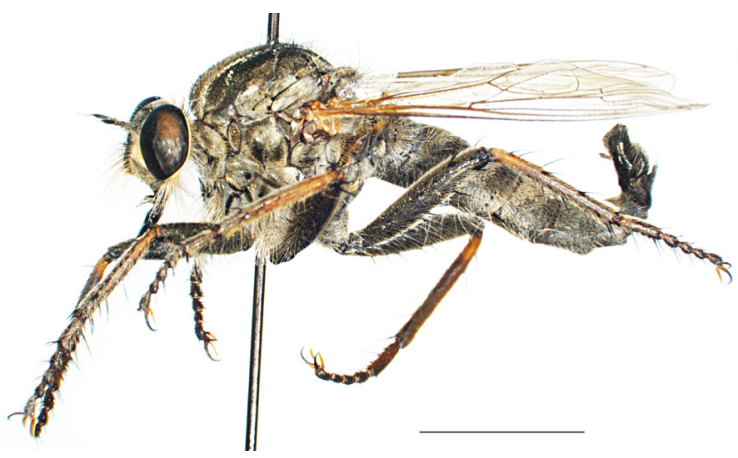

Fig .10. Machimus gonatistes (Zeller, 1840). Male (Scale $5 \mathrm{~mm}$ ). 
ÇALIŞKAN, H., ŞIRIN, D.Ü., ASLAN, A., FIDAN, E.C, \& ŞAHIN, Y.

As a result, 4 species are found in the Thrace Region and one species in both Thrace and Anatolian sides in the study. Undoubtedly, new studies are needed to determine the existence and distribution of these species in Anatolia. Based on the results of the study, we think that it is possible to discover many new records or perhaps new species in future studies on Turkish robber fly fauna.

\section{ACKNOWLEDGEMENTS}

This research was supported by The Scientific and Technological Research Concil of Turkey (TUBITAK) (TBAG-2050/101T061) and Eskişehir Osmangazi University Scientific Research Projects Commission (Project Number: 2018-1987).

\section{REFERENCES}

Adamovic, Z.R. (1966). Ecological differences of some closely related species. Ekologija. (1), 121-131.

Aral-Alpay, A.N. (2011). Systematic and faunistic evaluation of Machimus (Diptera, Asilidae) genus group of Orta Toros Mountains. PhD Thesis. Gazi University Instute of Science and Technology. 1-160.

Aral-Alpay, A.N., Aktaş, M., \& Hasbenli, A. (2007). Contributions to the Leptogastrinae fauna of Turkey (Diptera: Asilidae). International Journal of Dipterological Research. 18(1), 7-13.

Astakhov, D.M. (2015). Robber flies (Diptera, Asilidae) of Lower Volga Area. Proceedings of the Russian Entomological Society, 86(1), 1-410.

Bayrakdar, F. \& Hasbenli, A. (2009). Contribution to the geographic distribution of Dioctria Meigen, 1803 Genus (Diptera, Asilidae). Turkish Journal of Zoology, 33, 23-26.

Bosak, J. \& Hradsky, M. (2001). Some remarks on the distribution of robberflies (Diptera: Asilidae) in Turkey. Journal of Entomological Research Society, 3(3), 1-28

Cannings, R.A. (2002). The systematics of Lasiopogon (Diptera: Asilidae) Victoria (British Columbia): Royal British Columbia Museum, 354 pp.

Çalışkan, H. (2003). New records of robber flies (Diptera, Asilidae) for the Turkish fauna. Journal of the Entomological Research Society, 5(1), 21-32.

Çalışkan, H. (2010). A new record for Turkish Asilidae (Insecta: Diptera) fauna: Pamponerus germanicus (Linnaeus, 1758). Journal of Engineering and Architecture Faculty of Eskişehir Osmangazi University, 23, 1.

Durmuş, Y. (1999). Ankara çevresi Asilidae (Diptera) familyasının faunistik ve sistematik yönden araştıııması. Master Thesis. Gazi University Institute of Science and Tecnology, Ankara, 1-135.

Engel, E.O. (1930). Asilidae In E. Lindner (Ed.). Die Fliegen der Pälearktischen Region. Band Schweizerbart, Stuttgart, 4(2), 1-491.

Ghahari, H., Hayat, R., Lavigne, R.J., \& Ostovana H. (2014). An annotated checklist of Iranian Asilidae (Insecta: Diptera: Brachycera: Asiloidea). Linzer Biologisce Beitrage, 46(2), 1379-1446.

Geller-Grimm, F. (2015). Robber flies (Asilidae) database, Retrieved from http://www.geller-grimm.de/ catalog/species.htm (14.10.2020)

Geller-Grimm, F., Dikow, T., \& Lavinge, R.J. (2020, October, 14). Asilidae database. Content, structure, Retrieved from http://www.geller-grimm.de/asilidae.htm

Giray, H. (1981). A preliminary list of the fauna of Turkish Asilidae (Diptera). Plant Protection Bulletin, 5(3), 171-183.

Hasbenli, A. \& Bayrakdar, F. (2006). Contribution to geographic distribution of Neoitamus Osten-Sacken, 1878 (Diptera: Asilidae). Dipterological Research - An International Journal of Dipterological Research, 17(2), 99-100. 
Five New Records for Turkish Robber Flies (Diptera: Asilidae) Fauna

Hasbenli, A. \& Cağlar, Ü. (2009). A New species of Mesoleptogaster (Diptera: Asilidae) from Turkey, with a key to Palaearctic species. Entomological News, 120(2), 201-205. DOl:http://doi.org/10.3157/021.120.0212

Hasbenli, A., Çiftçi, D., \& Çağlar, Ü. (2020). Tanap, a new robber fly genus from Turkey (Diptera: Asilidae: Dioctriinae). Zootaxa, 48822(1), 113-120. DOI: https://doi.org/10.11646/zootaxa.4822.1.6

Hasbenli, A. \& Geller-Grimm, F. (1999). Two new species of Dysmachus Loew, 1860 (Asilidae: Diptera) from Turkey. Journal of the Entomological Research Society, 1(1), 13-19.

Hasbenli, A., Candan, S., \& Alpay, N. (2006a). A new species of Leptogaster Meigen (Diptera, Asilidae) from Turkey with egg and spermatheca structure. Zootaxa, 1267, 49-57.

Hasbenli, A., Bayrakdar, F., \& Alpay, N. (2006b). First record of Erax nigrosetosus Theodor, 1980 (Diptera: Asilidae). Acta Entomologica Slovenica, 14(1), 103-106.

Hayat, R. \& Alaoglu, Ö. (1994). Faunistic and systematics studies on the Asilidae (Diptera) species in Erzurum and neighbouring provinces I. Laphriinae and Stenopogoninae. Türkiye 3. Biyolojik Mücadele Kongresi. Izmir, 123-135.

Hayat, R. \& Alaoglu, Ö. (1996a). Faunistic and systematics studies on the Asilidae (Diptera) species in Erzurum and neighbouring provinces II. Laphystinae, Stichopogoninae, Dasypogoninae, Leptogastrinae and Apocleinae. Atatürk University Journal of Agriculture Faculty, 27(1),111-120.

Hayat, R. \& Alaoglu, Ö. (1996b). Faunistic and systematics studies on the Asilidae (Diptera) species in Erzurum and neighbouring provinces III. Asilinae. Atatürk University Journal of Agriculture Faculty, 27(1), 121-138.

Hayat, R. \& Özbek, H. (1994). New records of robber flies (Diptera: Asilidae) for Turkish fauna. Turkish Journal of Entomology, 18(4), 241-244.

Hayat, R. \& Özbek, H. (1999). The Genus Dasypogon Meigen, 1803 (Diptera: Asilidae) in Turkey, along with new records. Acta Entomologica Bulgaria, 1, 42-47.

Jansens, E. (1968a). Asilidae (Diptera) de Turquie. Asilidae (Diptera) de Turquie. Bulletin de l'Institut Royal des Sciences Naturelles de Belgique, 44(2), 1-13.

Jansens, E. (1968b). Asilidae de Turquie et regions voisines (deuxieme note). Bulletin de L'institiut Royal des Sciences Naturelles de Belgique, 44(33), 1-8.

Lehr, P.A. (1963). Review of robber flies of the genus Stenopogon Loew (Diptera, Asilidae). Trudy Instituta Zoologii Akademii Nauk Kazakhskoi, SSR21, 96-14.

Lehr, P.A. (1984). Assassin flies of the tribe Stichopogonini (Diptera, Asilidae) from the fauna of the USSR.1. Institute of Biology and Pedology, Far East Science Center of the USSR Academy of Science (Vladivostok). Zoologicheskii Zhurnal, 63, 696-706.

Lehr, P.A. (1986). Survey of robber-flies subtribe Machimina Lehr (Diptera, Asilidae). Communication 2. The genus Antiphrisson Loew, 1847. In P.A. Lehr (Ed.). Systematics and ecology of insects from the Far East. - Vladivostock: Akademiya Nauk, SSSRD: 155, 117-147.

Lehr, P.A. (1988). Asilidae. In A. Soos, L. Papp (Eds.). Catalogue of palearctic Diptera. Amsterdam, Elsevier Science Publishing Co. Inc.

Lehr, P. A. (1992). 'Small' genera of robberflies of the subfamily Asilinae (Diptera, Asilidae). 1.Taxonomy and Ecology. Zoologichesky Zhurnal, 71(5), 91-105.

Richter, V.A. (1964). Zoogeographic features of the robber fly fauna (Dipt., Asilidae) of the Caucasus. Entomological Review [russian: Entomologiceskoe Obozreniye], 43(2), 170-176.

Sakhvon, V.V. \& Caxboh, B.B. (2015). A contribution to the fauna of robber flies (Diptera: Asilidae) of Belarus. Zoosystematica Rossica, 24(2), 292-302.

Schiner, J.R. (1862). Fauna Austriaca, Die Fliegen (Diptera). Wien: C. Gerolds Sohn, 1862-64.

Séguy, E. (1927). Fauna de France. 17 Asilidae, Diptères (Brachycères). Faune de France 17, 184.

Shurovnekov, B.G. (1962). Field entomophagous predators (Coleoptera, Carabidae, and Diptera, Asilidae) and factors determining their efficiency. Entomological Review, 41, 476-485. 
ÇALIŞKAN, H., ŞIRIN, D.Ü., ASLAN, A., FIDAN, E.C, \& ŞAHIN, Y.

Theodor, O. (1976). On the structure of the spermathecae and aedeagus in the Asilidae and their importance in the systematics of the family. The Israel Academy of Sciences and Humanities, 175p.

Theodor, O. (1980). Diptera: Asilidae. Fauna Palaestina. Insecta, 11. Jerusalem

Tomasovic, G. (1999a). Notes sur les Asilidae paléarctiques (Diptera Brachycera) (10 et 11).Description et répartition géographique de 2 espèces nouvelles de Dasypogon du groupe diadema (Fabricius, 1781). Bulletin de la Societé royale Belge d'Entomologie, 135, 216-221.

Tomasovic, G. (1999b). Notes sur les Asilidae paléarctiques (Diptera Brachycera) (12 et 13). Andrenosoma cornuta Oldroyd, 1972, Leptogaster subtilis Loew, 1847, et Satanas gigas (Evers, 1855). Bulletin de la Societé royale Belge d'Entomologie, 135, 221-222.

Tsacas, L. (1968). Révision des espèces du genre Neomochtherus Osten-Sacken (Asilidae). I.Région Paléarctique: Memoires du Museum national d'Histoire naturelle. Serie A - Zoologie N.S, 47(3), 127-328.

Weinberg, M. \& Bachli, G. (1995). Diptera Asilidae. Insecta Helvetica. Fauna. II.Genève: Schweizerische Entomologische Gesellschaft, 1-124.

Weinberg, M. \& Hayat, R. (1997). Asilidae (Diptera) Recorded in Turkey. Travaux du Museum d'Histoire Naturelle 'Grigore Antipa', 39, 161-168.

Zeller, P.C. (1840). Beitrag zur Kenntnis der Dipteren aus den Familien der Bombylier, Anthracier und Asiliden. Isis von Oken Leipzig, 1840, 10-77. 